\title{
KONSTRUKSI REALITAS PEREMPUAN DI MEDIA SUARA NTB
}

\author{
M. Tamarin \\ Email: tamrinlombok@gmail.com
}

\begin{abstract}
This paper aims to find out how the construction of the reality of women in the mass media is formed in the reporting and trafficking of people with female victims in the Mass Media. This study focused on the text of the news of rape and trafficking in women in May 2016 in the NTB Suara daily. This paper is a qualitative study using the Teun Van Dijk model discourse analysis method. With this method, the committee will see how women's discourse is constructed and shaped by mass media through text analysis, social cognition and social contexts. The conclusion is that Suara NTB daily constructs women as victims, not as objects of exploitation, because women are placed as the subject of the narrator and given space to tell themselves or the events experienced.
\end{abstract}

Keywords: Discourse Analysis, Construction, News, Rape, Gender 


\begin{abstract}
Abstrak
Paperinibertujuan untuk mengetahuibagaimanakonstruksi realitas perempuan di media massa yang dibentuk dalam pemberitaan dan perdagangan manusia dengan korban perempuan di di Media Massa. Kajian ini difokuskan pada teks berita pemerkosaan dan perdagangan perempuan pada bulan Mei 2016 di harian Suara NTB.Paper ini merupakan studi kualitatif yang menggunakan metode analisis wacana model Teun van Dijk. Dengan metode tersebut, panulis akan melihat bagaimana wacana perempuan dikonstruksi dan dibentuk oleh media massa melalui analisis teks, kognisi sosial dan konteks sosial.Kesimpulannya bahwa harian Suara NTB mengonstruksikan perempuan sebagai korban, bukan sebagai objek eksploitasi karena perempuan ditempatkan sebagai subjek pencerita dan diberi ruang untuk menceritakan dirinya atau peristiwa yang dialami.
\end{abstract}

Kata kunci:Analisis Wacana, Konstruksi, Berita, Pemerkosaan, Gender

\section{A. Pendahuluan}

Dalam sebuah produk media massa terutama media cetak, dalam hal ini adalah majalah, buletin, maupun surat kabar, secara umum terdiri dari dua bagian yaitu fakta dan opini. Bagian yang berisi fakta terdapat pada rubrik berita dan menjadi mayoritas isi sebuah surat kabar. Sedangkan bagian yang berisi opini terdapat pada rubrik opini/ artikel yang ditulis baik oleh pihak media maupun masyarakat umum.

Karena sifat dan faktanya bahwa pekerjaan media massa adalah menceritakan peristiwa-peristiwa, maka tugas utama media massa adalah mengkonstruksi berbagai realitas yang akan diinformasikan. Semua unsur peristiwa atau realitas, yangterdiridarikejadian, opiniorang, situasi dan kondisi, dipersepsi dan direkam oleh wartawan. Kemudian wartawan melakukan identifikasi, menyeleksi, mesistematisasi, memberi struktur pada fakta-fakta hasil observasi tersebut. Fakta-fakta hasil persepsi dan observasi, berupa "rekaman" peristiwa merupakan realitas yang selanjutnya akan disusun dan ditulis menjadi berita. Dengan demikian berita merupakan hasil konstruksi realitas dalam bentuk wacana bermakna. ${ }^{1}$

1 Mursito BM, Jurnalistik Komprehensif, (Jakarta: Literate, 2013), 70-71. 
Dalam menyajikan berita, hanya peristiwa-peristiwa yang mempunyai news value dan menarik perhatian publik saja yang akan menjadi fokus utama pemberitaan di media. Dimana salah satu peritiwa yang nemiliki news value dan menarik perhatian adalah peristiwa kekerasan yang akan dibahas dalam permasalah ini.

Semua bentuk realitas antara lain realitas simbolik, realitas objektif, realitas subjektif, realitas sosial adalah bahan muatan berita di media. Untuk sederhananya, semua realitas itu kita sebut saja realitas empirik. Jadi realitas media adalah realitas empirik yang dikonstruksi media menjadi berita dan formatformat informasi yang lain, seperti feature, pojok, artikel dan infotaiment. ${ }^{2}$ Seperti yang dikatakan Van Peursen, realitas bukan suatu substansi atau kata benda, tetapi mengacu pada suatu aturan. ${ }^{3}$

Dalam proses konstruksi realitas, bahasa merupakan unsur utama. Dimana bahasa merupakan instrumen pokok untuk menceritakan realitas. Bahasa adalah alat konseptualisasi dan alat narasi. Dalam konteks media massa, keberadaan bahasa tidak lagi sebagai alat semata untuk menggambarkan

2 Mursito BM, Realitas Media (Solo: Smmart Media. 2012), 7

3 Ibid., hlm. 7-8. sebuah realitas, melainkan bisa menentukan gambaran (makna citra) mengenai suatu realitas media yang akan muncul di benak pembaca. Oleh karena persoalan makna itulah, maka penggunaan bahasa berpengaruh terhadap konstruksi realitas, terlebih atas makna atau citra yang dihasilkan. Penggunaan bahasa tertentu dengan demikian akan berimplikasi pada bentuk konstruksi realitas dan makna tertentu pula yang dikandungnya.

Dalam penulisan berita di media massa kekerasan menjadi salah satu tema yang memiliki daya tarik sendiri untuk pembaca. Oleh karena itu, terkadang pemberitaan tentang kekerasan dibuat sedikit berlebihan untuk menarik pembaca, terutama kekerasan terhadap perempuan. Berikut contoh pemberitaan tentang kekerasan yang dibuat oleh media "Kekerasan Seksual pada Anak di Dompu Menghawatirkan". ${ }^{4}$ Dari pemilihan kata pada judul tersebut menunjukkan bahawa perempuan selalu berada pada posisi termarjinalkan.

Data kasus kekerasan terhadap perempuan dari tahun ke tahun terus meningkat. Tercatat pada tahun 2013 ada 279.760 kasus kekerasan terhadap perempuan. Sedangkan pada tahun 2012 tercatat 216.156

4 SKH Suara NTB Edisi 7 Mei 2016. 
kasus dan 119.107 kasus pada tahun 2011. ${ }^{5}$ Seperti tahun-tahun sebelumnya, kekerasan yang terjadi di ranah personal tercatat sebagai kasus paling tinggi di tahun 2013 yaitu 275.004 kasus. 270.833 kasus diantaranya berupa kasus kekerasan terhadap istri, dimana 263.285 kasus merupakan kasus yang ditangani oleh 359 Pengadilan Agama di Indonesia dan 7.548 kasus lainnya merupakan kasus yang ditangani oleh mitra padalayanan pemerintah; 2.507 kasus kekerasan dalam pacaran; 844 kasus kekerasan terhadap anak perempuan dan 667 kasus kekerasan dalam relasi personal lainnya.

Dimana kekerasan fisik masih menempati urutan tertinggi, yaitu 4.631 kasus, di urutan kedua kekerasan psikis sebanyak 3.344 kasus, disusul kekerasan seksual sebanyak 2.995 kasus dan kekerasan ekonomi sebanyak 749 kasus. Meskipun berada di urutan ketiga, laporan kasus kekerasan seksual meningkat sebanyak $17 \%$ jika dibandingkan pada tahun $2012 .{ }^{6}$

5 Direktorat Kependudukan, "Pemberdayaan Perempuan dan Perlindungan Anak BAPPENAS, Pembangunan Kesetaraan Gender Background Study RPJMN III (2015-2019)", (Jakarta: Kementerian Perencanaan Pembangunan Nasional/ Badan Perencanaan Pembangunan Nasional (BAPPENAS), 2013), 74.

6 Komnas Perempuan, "Lembar Fakta Tahunan (CATAHU) Komnas Perempuan Tahun 2013" (Jakarta: Komnas Perempuan, 2014), 1.
Ketidakadilan gender terwujud dalam berbagai bentuk ketidakadilan seperti marginalisasi atau proses pemiskinan ekonomi, subordinasi atau anggapan tidak penting dalam mengambil suatu keputusan, pembentukan stereotype melalui pelabelan negatif, kekerasan (violence), beban kerja lebih panjang dan lebih banyak serta sosialisasi ideologi nilai peran gender. ${ }^{7}$ Kondisi ketidakadilan gender yang terus-menurus berlangsung dan memunculkan anggapan yang salah terhadap gender inilah yang kemudian disebut dengan bias gender.

Media massa dan konsep gender selamainisalingmemilikiketerkaitan, terutama jika menyangkut masalah perempuan. Perempuan dan media massa, dua aspek yang tidak dapat dipisahkan satu dengan lainnya. Hampir tidak ada satu jenis media massa pun saat ini yang tak mengangkat sosok perempuan dalam pemberitaan. Media pun turut andil dalam mempengaruhi persepsi masyarakat terhadap bias gender yang berkembang selama ini, terutama terhadap perempuan.

Selama ini produksi dan pencitraan media massa lebih mengarah pada dominasi laki-laki

7 Mansour Fakih, Analisis Gender dan Transformasi Sosial,(Yogyakarta: Pustaka Pelajar, 2010), 12. 
dibandingkan perempuan. Laki-laki lebih sering ditampilkan sebagai sosok pemimpin, kuat, berkuasa dan mandiri sementara perempuan sebaliknya. Sosok perempuan oleh media massa, baik melalui iklan atau beritanya, selalu dideskripsikan secara negatif dan sangat tipikal yaitu tempatnya perempuan ada di rumah, berperan tunggal sebagai ibu rumah tangga dan pengasuh, tergantung pada laki-laki, menjalani profesi secara terbatas, tidak mampu membuat keputusan penting. Eksistensi perempuan pun tidak terwakili secara proporsional di media massa, entah dalam industri media hiburan atau dalam industri media berita. ${ }^{8}$

Sara Mills yang melihat teks berita dari perspektif wacana feminis mengatakan bahwa perempuan cenderung ditampilkan dalam teks sebagai pihak yang salah, marjinal dibandingkan pihak lakilaki. ${ }^{9}$ Hal tersebut sering muncul dalam pemberitaan seperti kasuskasus perkosaan dan pelecehan terhadap perempuan yang tidak saja menampilkan perempuan

8 Setiawan, Yulianto Budi, "Analisis Wacana Kritis Pemberitaan Kekerasan Berbasis Gender di Surat Kabar Harian Suara Merdeka”, Jurnal Ilmiah Komunikasi MAKNA, (Volume 2 Nomor 1 Februari,2011).

9 Eriyanto,Analisis Wacana: Pengantar Analisis Teks Media,(Yogyakarta: LkiS, 2001), 199. sebagai objek berita namun juga menyertainya dengan berbagai pernyataan yang memposisikan perempuan sebagai pihak yang juga patut dipersalahkan karena dipandang ikut andil menyebabkan kasus itu terjadi (stereotype).

\section{B. Konstruksi Realitas}

Istilah konstruksi realitas menjadi terkenal sejak dipublikasikan oleh Peter L. Berger dan Thomas Luckman melalui bukunya The Social Construction of Reality yang di dalamnya digambarkan proses sosial melalui tindakan dan interaksinya dimana individu secara intens menciptakan suatu realitas yang dimiliki dan dialami bersama secara subjektif. Oleh karena itu, pemahaman terhadap sesuatu bisa terjadi akibat kita berkomunikasi dengan orang lain. Realitas sosial sesungguhnya tidak lebih dari sekedar hasil konstruksi sosial dalam komunikasi tertentu. ${ }^{10}$

Berger \& Luckman berpandangan bahwa kenyataan itu dibangun secara sosial, dalam pengertian individu-individu dalam masyarakat itulah yang membangun masyarakat. Maka pengalaman individu tidak terpisahkan dengan

10 Alex Sobur, Analisis Teks Media: Suatu Pengantar untuk Analisis Wacana, Analisis Semiotik, dan Analisis Framing, (Bandung: Remaja Rosdakarya, 2012), 91. 
masyarakatnya. Berger memandang manusia sebagai pencipta kenyataan sosial yang objeketif melalui tiga momen dialektis yang simultan yaitu eksternalisasi, objektivasi dan internalisasi.

Eksternalisasi, yaitu usaha pencurahan atau ekspresi diri manusia ke dalam dunia, baik dalam kegiatan mental maupun fisik. Proses ini merupakan bentuk ekspresi diri untuk menguatkan eksistensi individu dalam masyarakat. Pada tahap ini masyarakat dilihat sebagai produk manusia (society is a human product).

Objektifikasi, adalah hasil yang telah dicapai, baik mental maupun fisik dari kegiatan eksternalisasi manusia tersebut. Hasil itu berupa realitas objektif yang hadir dalam wujud yang nyata. Realitas objektif itu berbeda dengan kenyataan subjeketif perorangan. Ia menjadi kenyataan empiris yang bisa dialami oleh setiap orang. Pada tahap ini masyarakat dilihat sebagai realitas yang objektif (society is an objective reality), atau proses interaksi sosial dalam dunia intersubjektif yang dilembagakan atau mengalami proses institusionalisasi.

Internalisasi, lebih merupakan penyerapan kembali dunia objektif ke dalam kesadaran sedemikian rupa sehingga subjektif individu dipengaruhi oleh struktur dunia sosial. Berbagai macam unsur dari dunia yang telah terobjektifikasi tersebut akan ditangkap sebagai gejala realitas di luar kesadarannya, sekaligus sebagai gejala internal bagi kesadaran. Melalui internalisasi manusia menjadi hasil dari masyarakat (man is a social product).

Eksternalisasi, objektifikasi dan internalisasi adalah tiga dialektis yang simultan dalam proses reproduksi. Secara berkesinambungan adalah agen sosial yang mengeksternalisasi realitas sosial. Pada saat yang bersamaan, pemahaman akan realitas yang dianggap objektif pun terbentuk. Pada akhirnya, melalui proses eksternalisasi dan objektifasi, individu dibentuk sebagai produk sosial. Sehingga dapat dikatakan, tiap individu memiliki pengetahuan dan identitas sosial sesuai dengan peran institusional yang terbentuk atau yang diperankannya.

Mursito BM dalam bukunya Jurnalisme Komprehensif mengutip pendapat dari Van Peursen tentang realitas:

Realitas bukan suatu objek. Karena bukan suatu objek melainkan aturan, ia merupakan semacam norma, semacam kriteria untuk mencapai pengetahuan yang benar dan pengamatan yang bermakna. Dalam arti itu dapat dikatakan 
bahwaistilahrealitasmenunjukan syarat bagi pengetahuan objektif, atau dalam bahasa filsafat realitas bersifat transendental. ${ }^{11}$

Karena realitas merupakan suatu aturan atau norma, maka akan dijumpai beberapa bentuk realitas, yakni realitas subjektif, realitas simbolik, realitas objektif, dan realitas media. Realitas objektif adalah realitas yang terbentuk dari pengalaman di dunia objektif yang berada di luar diri individu, dan realitas ini dianggap sebagai kenyataan. Realitas simbolis merupakan ekspresi simbolis dari realitas objektif dalam berbagai bentuk. Sedangkan realitas subjektif adalah realitas yang terbentuk sebagai proses penyerapan kembali realitas objektif dan simbolis ke dalam individu melalui proses internalisasi. ${ }^{12}$

Proses konstruksi realitas yang dilakukan oleh media merupakan usaha "menceritakan" (konseptualisasi) sebuah peristiwa atau keadaan. ${ }^{13}$ Realitas tersebut tidak serta merta melahirkan berita,

11 Mursito BM, Jurnalisme..., 72.

12 Burhan Bungin, Konstruksi Sosial Media Massa: Kekuatan Pengaruh Media Massa, Iklan Televisi, dan Keputusan Konsumen Serta Kritik Terhadap Peter L. Berger dan Thomas Luckmann,(Jakarta: Kencana,2008), 24.

13 Ibnu Hamad,Konstruksi Realitas Politik dalam Media Massa,(Yogyakarta: Granit,2004), 11. melainkan melalui proses interaksi antara penulis berita, atau wartawan, dengan fakta.

Konstruktivisme memandang realitas sebagai sesuatu yang ada dalam beragam bentuk konstruksi mental yang didasarkan pada pengalaman sosial, bersikap lokal dan spesifik, serta tergantung pada pihak yang melakukannya. Pembuatan berita pada dasarnya merupakan proses penyusunan atau konstruksi kumpulan realitas sehingga menimbulkan wacana yang bermakna.

Isi media pada hakikatnya adalah hasil konstruksi realitas dengan bahasa sebagai perangkat dasarnya. Sedangkan bahasa bukan hanya sebagai alat merepresentasikan realitas, namun juga bisa menentukan relief seperti apa yang akan diciptakan oleh bahasa tentang realitas tersebut. Akibatnya, media massa mempunyai peluang yang sangat besar untuk mempengaruhi makna dan gambaran yangdihasilkan dari realitas yang dikonstruksikannya itu. ${ }^{14}$

Realitas adalah produk interaksi antarawartawandanfakta. Wartawan melakukan objektivikasi atau melakukan persepsi terhadap suatu realitas. Dalam proses internalisasi, hasil persepsi dari realitas tersebut

14 AlexSobur,Analisis Teks Media..., 88. 
diserap dalam kesadaran wartawan. Kemudian pada proses eksternalisasi, wartawan menceburkan dirinya untuk memahami realitas. Konsepsi tentang fakta untuk melihat realitas diekspresikan melalui pernyataan dan alat untuk membuat pernyataan itu adalah bahasa. Dengan demikian, teks berita yang kita baca di surat kabar atau kita dengar di televisi dan radio adalah produk dari proses interaksi dan dialektika tersebut atau pendek kata merupakan hasil konstruksi realitas.

Dari sisi konstruksionis, media, wartawan, dan berita memiliki keterkaitan sebagai berikut:

- Fakta atau peristiwa adalah hasil konstruksi karena melibatkan sudut pandang tertentu dari wartawan.

- Media merupakan agen konstruksi karena dia bukan saluran yang bebas.

- Berita bukan refleksi dari realitas, melainkan konstruksi dari realitas tersebut.

- Hasil dari konstruksi tersebut, berita bersifat subjektif.

- Wartawan merupakan agen konstruksi realitas karena tidak dapat menyembunyikan rasa keberpihakan, etika, dan pilihan moral dalam menyusun berita tersebut, secara intrinsik.
Realitas didefinisikan secara terus menerus melalui praktik bahasa, yangbermakna sebagaipendefinisian selekif terhadap realitas yang ditampilkan. Hal ini mengakibatkan suatu persoalan atau peristiwa di dunia nyata tidak mengandung atau menunjukkan makna integral, tunggal dan intrinsik. Makna yang muncul hanyalah makna yang ditunjukkan melalui bahasa. Bahasa dan simbolisasi adalah perangkat yang memproduksi makna.

Fungsi Bahasa yang paling utama adalah sebagai sarana komunikasi. Halliday mengemukakan tiga meta fungsi bahasa, yang berhubungan dengan penggunaan bahasa dalam proses sosial di dalam suatu masyarakat. Ketiga meta fungsi tersebut antara lain: ${ }^{15}$

1. Fungsi ideasional (ideational function)

Berkaitan dengan peranan bahasa untuk mengungkapkan ide, gagasan, dan isi pikiran, serta untuk merefleksikan realitas pengalaman partisipannya.

2. Fungsi interpersonal (interpersonal function)

Berkaitan dengan peranan bahasa untuk membangun dan memelihara hubungan sosial, untuk mengungkapkan peranan-

15 Ibnu.Hamad, Konstruksi Realitas..., 12. 
peranan sosial dan peranan komunikasi yang diciptakan oleh bahasa itu sendiri.

3. Fungsi tekstual (textual function)

Berkaitan dengan peranan bahasa untuk membentuk berbagai mata rantai kebahasaan dan mata rantai unsur situasi yang memungkinkan digunakannya bahasa oleh para pemakainya. Secara singkat fungsi bahasa disini untuk menyediakan kerangka, wacana yang relevan terhadap situasi.

Lebih jauh, konstruksi sosial pada media cetak mencakup pada pengaturan kata-kata membentuk frase, klausa, atau kalimat yang bermakna untuk menjelaskan atau menggambarkan suatu kualitas atau keadaan aktual, benar, atau nyata dan dipublikasikan di media cetak. ${ }^{16}$

Tom Wolf menjelaskan tentang konstuksi realitas yang dikutip Nurudin, tulisan harus merupakan konstruksi dari adegan per adegan. Dengan kata lain tulisan merupakan gaya bertutur dengan susunan mirip skenariofilm.Dalamjurnalismebaru, penciptaan adegan diperkirakan bisa membuat pembaca memahami perubahan cerita dengan sendirinya, tanpa harus dijelaskan. ${ }^{17}$

16 Ibid.,

17 Nurudin,Jurnalisme Masa Kini,(Jakarta: Rajawali Pers,2009), 185.
Untuk memahami konstruksi realitas sosial oleh media massa yang tertuang dalam teks berita dapat dilihat melalui analisis teks. Sebagaimana fokus dalam paper ini adalah teks berita. Teks berfungsi untuk membangun realitas. Secara linguistik, teks dapat dianalisis dengan melihat kosakata, sintaksis, dan semantiknya. Prinsip koherensifitas, hubungan antar kata dan antar kalimat juga diperhatikan dalam membentuk pengertian.

\section{Media Massa dan Gender}

Media cetak adalah bagian dari media massa. Media massa sering digunakan sebagai alat teknik yakni sebagai tempat terjadinya komunikasi massa. Media massa dapat meliputi, (1) media cetak seperti surat kabar, majalah, buku, pamflet, billboards, dan alat tehnik lainnya yang membawa pesan kepada massa dengan cara menyentuh indera penglihatan, (2) media elektronik seperti program radio dan rekaman yang menyentuh indera pendengaran, dan program televisi, gambar bergerak dan rekaman video yang menyentuh kedua indra pendengaran dan penglihatan. ${ }^{18}$

Media yang termasuk dalam media cetak di antaranya, koran,

18 Reed HBlake \& Edwin O. Haroldsen, Taksonomi Konsep Komunikasi, (Surabaya: Papyrus, 2003), 42. 
tabloid, majalah, dan buku. ${ }^{19}$. Media cetak adalah bagian dari media massa. Media dalam arti luas, yaitu segala sarana yang terkait dengan penyampaian pesan, baik yang bersifat riil maupun simbolik, dari sebuah institusi kepada masyarakat luas. ${ }^{20}$ Media dalam hal ini dapat berupa televisi, radio, majalah, dan koran. Media pun kerap kali digunakan sebagai instrumen untuk mengkomunikasikan ide, pesan, danprogram kerja karena kenyataannya media dapat dipakai untuk menyampaikan pesan kepada masyarakat luas dengan biaya atau orang yang relatif sangat murah.

Media cetak dalam paper ini berperan sebagai medan pengkonstruksian realitas. Arti penting media massa dalam komunikasi membuat medan pertempuran dan persaingan untuk membentuk opini publik terfokus pada media. Masingmasing kepentingan akan berusaha mendekati media massa tertentu yang memiliki jaringan luas dalam masyarakat. Firmanzah mengatakan keberpihakan media massa terhadap persoalan bisa menguntungkan dan merugikan image seseorang di

19 JohnVivian, Teori Komunikasi Massa,(Jakarta: Kencana, 2008), 10.

20 Firmanzah.,Mengelola Partai Politik: Komunikasi dan Positioning IdeologiPartai Politik di Era Reformasi,(Jakarta: Yayasan Obor, 2011), 28. mata masyarakat. Menguntungkan, karena masyarakat dapat dengan mudah mengidentifikasi ideologi yang dikeluarkan oleh media massa. Merugikan karena hal ini dapat mengurangi pangsa pasar mereka. ${ }^{21}$ Sementara itu, media massa juga dapat bersikap netral. Dalam aliran ini, mereka menerima dan mempublikasikan siapa pun yang dianggap layak dipublikasikan. Paper ini membatasi media cetak pada media surat kabar yang terbit harian di NTB dengan, yakni Suara NTB,

Selanjutnya, untuk memahami konsep gender harus dibedakan kata gender dan seks (jenis kelamin). Pengertian jenis kelamin merupakan pensifatan atau pembagian dua jenis kelamin manusia yang ditentukan secara biologis yang melekat pada jenis kelamin tertentu. Misalnya bahwa manusia jenis laki-laki adalah manusia yang memiliki atau bersifat seperti berikut ini: laki-laki adalah manusia yang memiliki penis, memiliki jakala (kala menjing), danmemproduksi sperma. Sedangkan perempuan memiliki alat reproduksi seperti rahim dan mempunyai saluran untuk melahirkan, memproduksi sel telur,

\footnotetext{
21 Ibid., 28.
} 
memiliki vagina, dan mempunyai alat menyusui. ${ }^{22}$

Artinya ada laki-laki yang emosional, lemah lembut, keibuan, sementara juga ada perempuan yang kuat, rasional dan perkasa. Perubahan ciri dari sifat-sifat tersebut dapat terjadi dari waktu ke waktu dan dari tempat ke tempat yang lain. Semua hal yang dapat dipertukarkan antara sifat perempuan dan laki-laki, yang bisa berubah dari waktu ke waktu serta berbeda dari tempat ke tempat lainnya, maupun berbeda dari suatu kelas ke kelas yang lain, itulah yang dikenal dengan konsep gender. $^{23}$

Perbedaan konsep gender antara laki-laki dan perempuan tidak akan menjadi masalah sepanjang tidak terjadi ketidakadilan gender (gender inequalities). Ketidakadilan gender terwujud dalam berbagai bentuk ketidakadilan seperti marginalisasi atau proses pemiskinan ekonomi, subordinasi atau anggapan tidak penting dalam mengambil suatu keputusan, pembentukan stereotype melalui pelabelan negatif, kekerasan (violence), beban kerja lebih panjang dan lebih banyak (burden) serta

22 Mansour Fakih,Analisis Gender dan Transformasi Sosial,(Yogyakarta: Pustaka Pelajar,2010), 7.

23 Ibid., 8. sosialisasi ideologi nilai peran gender. ${ }^{24}$

Media massa yang secara sederhana didefinisikan sebagai media yang digunakan dalam komunikasi massa, dalam hal inisurat kabar dan konsep gender selama ini saling memiliki keterkaitan, terutama jika menyangkut masalah perempuan. Perempuan dan media massa, dua aspek yang tidak dapat dipisahkan satu dengan lainnya. Media pun turut andil dalam mempengaruhi persepsi masyarakat terhadap bias gender yang berkembang selama ini, terutama jika terhadap perempuan.

Selama ini produksi dan pencitraan media massa lebih mengarah pada dominasi lakilaki dibandingkan perempuan. Media massa telah merefleksi dan mereproduksi rangkaian stereotipe sejalan dengan perubahan gender itu sendiri. Media massa telah mencitrakan perempuan dan lakilaki dari sudut pandang tertentu. ${ }^{25}$

Menurut Sita Aripurnani ada kecenderungan redaktur media massa dalam hal ini pers, memahami persoalan perempuan dalam konteks "news value" yang dianggap penting

24 Ibid., 12.

25 Haryati,"Konstrukvisme Bias Gender dalam Media Massa",Jurnal Citra Perempuan Dalam Media, (Vol.10. No. 1, 2012), 43. 
adalah berkaitan dengan hal-hal berikut: ${ }^{26}$

- Kekerasan terhadap perempuan, seperti perkosaan, penyiksaan isteri atau penganiayaan pembantu rumah tangga.

- Persoalan marginalisasi perempuan di dunia kerja, buruh buruh perempuan, posisi perempuan di dunia hukum, kesehatan dan pendidikan.

- Persoalan pandangan yang stereotipe dan diskriminatif terhadap perempuan.

- Gerakan pemberdayaan kaum perempuan dan isu isu gender lainnya.

Gejala demikian, jelas menunjukkan bahwa secara sadar atau tidak, media belum secara adil memperjuangkan kesetaraan antara perempuan dengan laki-laki. Terlebih jika dicermati identifikasi berita surat kabar yang dilakukan oleh May Lan (2002: 9-10), sebagai berikut: ${ }^{27}$

- Perempuan dalam berbagai berita di surat kabar masih menunjukkan bahwa mereka belum mengalami kesetaraan. Perempuan masih digambarkan sebagai sosok yang terbelakang,

26 Arifin, Hamid,"Representasi Perempuan dalam Pers",Jurnal Komunikasi Massa, (Vol.1. Nomor 1, 2007), 14.

27 Ibid., 15. tertindas dan tidak memiliki otoritas dirinya, apalagi terhadap masyarakat.

- Materi berita tentang perempuan yang disajikan dalam surat kabar masih sering menampilkan perempuan sebagai objek yang dieksploatasi, yaitu bagaimana perempuan digambarkan dan dimarjinalkan dalam teks berita melalui berbagai pola serta bentuk pemarjinalan.

- Frekuensi berita berkaitan dengan isu perempuan dan pemberdayaan tidaklah bersifat kontinyu, tetapi lebih mengarah kepada monumental, misalnya: Hari Kartini dan Hari Ibu.

- Dalam konteks berbagai berita di surat kabar, perempuan dan masalahnya mendapat porsi yang amat kecil, bahkan seringkali pemunculan itu hanya sebatas materi yang menjadi bahan tertawaan atau ejekan.

Krini Kafiris mengungkapkan ada beberapa cara untuk mengenali bias gender pada teks media massa, yaitu dengan mengamati bahasa, angle berita, konteks (context), narasumber (source), dan gambar (visual). ${ }^{28}$

Selain itu, menurut Sara Mills bias gender pada teks media massa

28 Haryati,"Konstrukvisme Bias Gender dalam Media Massa",Jurnal Citra Perempuan Dalam Media, (Vol.10. No. 1,2012), 44. 
juga dapat diamati melalui peletakan posisi atau representasi perempuan dalam berita. Dalam banyak kasus pemberitaan, umumnya kelompok bawah seperti petani yang tergusur, rakyat miskin di kota dan perempuan korban perkosaan dimarjinalkan dalam pemberitaan dan ditampilkan secara buruk. Mereka semua dalam teks ditampilkan sebagai objek, gambaran mereka ditampilkan oleh pihak lain. Bukan mereka yang bersuara, tetapi ditampilkan oleh kelompok lainlengkap dengan bias dan prasangkanya. ${ }^{29}$

\section{Konsep Analisis Wacana}

Analisis wacana adalah salah satu alternatif dari analisis isi, selain analisis isi kuantitatif yang dominan dan banyak dipakai. Jika analisis isi kuantitatif lebih menekankan pada pertanyaan "apa" (what), analisis wacana lebih melihat pada "bagaimana" (how) dari pesan atau teks komunikasi. Bukan hanya mengetahui bagaimana isi teks berita, analisis wacana juga melihat bagaimana pesan disampaikan. Lewat analisis wacana kita bisa melihat makna yang tersembunyi dari suatu teks.

Banyak model analisis wacana yang diperkenalkan dan dikembang-

29 Eriyanto, Analisis Wacana: Pengaantar Analisis Teks Media,(Yogyakarta: LkiS, 2001), 211-212. kan oleh para ahli. Eriyanto dalam buku Analisis Wacana-nya, menyajikan model-model analisis wacana yang dikembangkan, misalnya oleh Roger Fowler dkk. (1979), Theo Van Leeuwen (1986), Sara Mills (1992), Norman Fairclough (1998) dan Teun A. Van Dijk (1998). Dari sekian banyak model analisis wacana itu, model Van Dijk adalah model yang paling banyak dipakai. Karena Van Dijk mengolaborasikan elemen-elemen wacana sehingga bisa diaplikasikan secara praktis.

Model yang dipakai Van Dijk ini kerap disebut sebagai "kognisi sosial". Istilah ini sebenarnya diadopsi dari pendekatan lapangan psikologi sosial, terutama untuk menjelaskan struktur dan proses terbentuknya suatu teks. Namapendekataninitidak dapat dilepaskan dari karakteristik pendekatan yang diperkenalkan oleh Van Dijk. Menurut Van Dijk, paper atas wacana tidak cukup hanya didasarkan pada analisis atas teks semata, karena teks hanya hasil dari suatu praktik produksi yang harus juga diamati. Disini harus dilihat juga bagaimana bagaiman suatu teks diproduksi, sehingga kita memperoleh pengetahuan mengapa teks bisa semacam itu. ${ }^{30}$

30 Eriyanto, Analisis Wacana: Pengaantar Analisis Teks Medi, (Yogyakarta: LkiS, 2001), 221. 
Lebih lanjut, Encarnacion Hidalgo Tenorio dalam tulisannya menjelaskan analisis Van Dijk sebagai berikut:

Van Dijk's Socio-Cognitive Discourse Analysisis anapproach characterised by the interaction between cognition, discourse and society. It began in formal text linguistics and subsequently incorporated elements of the standard psychological model of memory, together with the idea of "frame" taken from cognitive science. A large part of van Dijk's practical investigation deals with stereotypes, the reproduction of ethnic prejudice, and power abuse by elites and resistance by dominated groups. $^{31}$

Istilah kognisi sosial van Dijk diadopsi dari pedekatan lapangan psikologi sosial, terutama untuk menjelaskan struktur dan proses terbentuknya suatu teks. Suatu teks yang cenderung memarjinalkan posisi wanita, misalnya, lahir karena kognisi atau kesadaran mental di antara wartawan bahkan kesadaran dari masyarakat yang memandang wanita secara rendah. Sehingga teks disini hanya bagian kecil saja dari praktek wacana yang merendahkan wanita. Oleh karena

31 Tenorio, Encarnacion Hidalgo, Critical Discourse Analysis, An Overview.(Journal University of Granada,. 2011.), 190. itu, paper mengenai wacana tidak bisa mengeksklusifkan seakan-akan teks adalah bidang yang kosong, sebaliknya ia adalah bagaian kecil dari struktur besar masyarakat. Pendekatan kognisi sosial membantu memetakan bagaimana produksi teks yang melibatkan proses yang kompleks tersebut dapat dipelajari dan dijelaskan.

Selain melalui koginisi sosial, ada konteks sosial yang mempengaruhi proses produksi teks. Dimana konteks sosial secara sederhana dipahami sebagai wacana yang berkembang dalam masayarakat, sehingga untuk meneliti teks perlu dilakukan analisis intertekstual dengan meneliti bagaimana wacana tentang suatu hal diproduksi dan dikonstruksi dalam masyarakat. ${ }^{32}$

\section{E. Analisis Berita Suara NTB}

Jika dilihat dari sudut pandang jurnalisme progender, pemilihan kosakata dan penjalinannya dalam bahasa kehidupan sehari-hari, baik yang tertuang dalam bahasa percakapan maupun tulisan-tulisan memang belum peka terhadap perempuan atau malah justru membentuk stereotype mengenai posisi dan status perempuan. Seperti contoh pemberitaan tentang

32 Eriyanto,Analisis Wacana: Pengaantar Analisis Teks Media, (Yogyakarta: LkiS,2001), 271. 
pemerkosaan dalam Harian Suara NTB dengan judul "Seorang Gadis Diduga Diperkosa Tukang Ojek" ${ }^{33}$. Kata "Diperkosa" disini bermakna penegasan sehingga kesan yang tampak dari berita tersebut menjadi hal yang biasa. Karena kata "diperkosa" merupakan sebuah kata penegasan terhadap peristiwa yang dialami. Dengan demikian, kasus perkosaan ini ingin ditunjukkan bahwa itu sebuah permasalahan yang menghantui setiap perempuan, karena penggunaan kata penegasan yakni "diperkosa".

Menurut Aliansi Jurnalistik Independen (AJI) pemberitaan berprespektif gender di Indonesia masih minim. Selain itu, berdasarkan paper yang dilakukan oleh Development and Peace (DnP) dan AJI pada tahun 2010, media massa Indonesia masih banyak menggunakan bahasa yang mengeksploitasi dan melecehkan perempuan, di samping masih adanya persentase berita yang tidak progender lebih tinggi dari berita progender. ${ }^{34}$

Suara NTB sebagai surat kabar bersegmentasi daerah tentunya juga turut memberitakan kasus-kasus kekerasan seksual dengan korban

33 SKH Suara NTB Edisi 7 Mei 2016.

34 Haryati, Konstrukvisme Bias Gender dalam Media Massa. Jurnal Citra Perempuan Dalam Media.(Vol. 10 No. 1,2012), 44. kaum perempuan yang terjadi di tengah-tengah masyarakat selama ini karena fenomena kekerasan seksual terhadap perempuan merupakan fenomena nasional. Sebagai salah satu barometer surat kabar di daerah, Suara NTB memiliki gaya penulisan yang berbeda dengan media lain yang ada di daerah. Bahasa yang digunakan media ini cenderung rapi dan tidak meletup-letup, meskipun jika dicermati isinya mengandung kritikan dan sindiran-sindiran tajam.

Berita yang dimuat di Suara NTB pun bukanlah sembarang berita. Berita yang dimuat merupakan hasil penggodokan yang matang baik dari sisi penulis atau wartawan maupun sisi editor. Berita yang dimuat di Suara NTB pun diarahkan pada masalah-masalah kedaerahan, dengan dimensi politik, sosial, ekonomi, kebudayaan dan seni yang diupayakan berimbang.

Oleh karena itu, untuk melihat bagaimana Suara NTB mengkonstruksi dan memberitakan citra terhadap kaum perempuan akan digunakan analisis wacana. Analisis wacana merupakan metode untuk mengkaji wacana yang terdapat pada pesan komunikasi. Isi pesan komunikasi yang dapat dikaji menggunakan metode ini sebagian di antaranya berupa analisis teks, termasuk dalam berita. Dengan demikian paper tentang isi media 
pada dasarnya diperlukan untuk memahami makna yang terkandung di dalam sebuah pesan komunikasi.

\section{F. Kesimpulan}

Setelah menjalaskan dan menganalisa bahasan-bahasan yang telah dipaparkan pada babbab sebelumnya, maka dapat disimpulkan bahwa konstruksi realitas perempuan di media massa yang dibentuk dalam pemberitaan mengenai pemerkosaan dan perdagangan terhadap perempauan di harian Suara NTB edisi Mei 2016, yaitu dengan menggunakan analisis wacana model Teun Van Dijk, maka peneliti dapat memberikan kesimpulan sebagai berikut:

- Suara NTB mengonstruksikan perempuan sebagai korban, bukan sebagai objek eksploitasi. Meskipun dalam penyajiannya, perempuan masih digambarkan sebagai sosok marjinal, lemah, tak berdaya dan sensitif namun dengan bahasa yang lebih halus dan rapi sesuai dengan ciri khas yang melekat pada Suara NTB. Ini terlihat dari pemberitaannya dengan menggunakan kata dan kalimat yang tidak meletup-letup, pemilihan narasumber yang sesuai dengan permasalahannya, dan yang paling penting adalah pencerita atau subyek berita yang berasal dari pihak berwajib yakni kepolisian yang memberikan data kepada wartawan sesuai dengan fakta, juga meminimalisir data yang tidakbenar, tidak akurat, dan mengedepankan asas peraduga tidak bersalah kepada pelaku.

- Wartawan di harian Suara NTB hanya berposisi sebagai pencari dan penyaji berita. Selain itu mereka juga memiliki andil dalam mengkonstruksi realitas dari berita yang disajikan dalam hal ini berita mengenai keriminal terhadap perempuan yang terjadi di Nusa Tenggara Barat (NTB). Namun, dalam pengkonstruksian realitas seutuhnya berada di tangan redaktur, sebab tugas utama wartawan hanyalah mencari berita, menyajikan berita, dan memberikannya kepada media tempatnya bekerja dalam hal ini harian Suara NTB selebihnya berada dalam kendali redaktur. 


\section{Daftar Pustaka}

Arifin, Hamid, Representasi Perempuan dalam Pers, (Jurnal Komunikasi Massa, Vol. 1 No. 1, 2007)

Blake, Reed H., Edwin O. Haroldsen,Taksonomi Konsep Komunikasi,(Surabaya:Papyrus, 2003)

BM,Mursito,Jurnalistik Komprehensif, (Jakarta: Literate, 2013)

Bungin, Burhan,Konstruksi Sosial Media Massa: Kekuatan Pengaruh Media Massa, Iklan Televisi, dan Keputusan Konsumen Serta Kritik Terhadap Peter L. Berger dan Thomas Luckmann, (Jakarta: Kencana, 2008)

Direktorat Kependudukan, Pemberdayaan Perempuan dan Perlindungan Anak BAPPENAS, Pembangunan KesetaraanGenderBackground Study RPJMN III (20152019), (Jakarta: Kementerian Perencanaan Pembangunan Nasional/ Badan Perencanaan Pembangunan Nasional (BAPPENAS), 2013)

Eriyanto, Analisis Wacana: Pengaantar AnalisisTeksMedia,(Yogyakarta: LkiS, 2001)

Fakih, Mansour,Analisis Gender dan TransformasiSosial,(Yogyakarta: Pustaka Pelajar, 2010)
Firmanzah, Mengelola Partai Politik: Komunikasi dan Positioning IdeologiPartai Politik di Era Reformasi, (Jakarta: Yayasan Obor, 2011)

Haryati, Konstrukvisme Bias Gender dalam Media Massa(Jurnal Citra Perempuan Dalam Media, Vol. 10 No. 1, 2012)

Komnas Perempuan, "Lembar Fakta Tahunan (CATAHU) Komnas Perempuan Tahun 2013" (Jakarta: Komnas Perempuan, 2014)

Nurudin,Jurnalisme Masa Kini, (Jakarta: Rajawali Pers, 2009)

Setiawan, Yulianto Budi,Analisis Wacana Kritis Pemberitaan Kekerasan Berbasis Gender di Surat Kabar Harian Suara Merdeka,(Jurnal Ilmiah Komunikasi MAKNA, Vol. 2 No. 1 Februari, 2011)

SKH Suara NTB Edisi 7 Mei 2016

Sobur, Alex,Analisis Teks Media: Suatu Pengantar untuk Analisis Wacana, Analisis Semiotik, dan Analisis Framing,(Bandung: Remaja Rosdakarya, 2012)

Tenorio, Encarnacion Hidalgo,Critical Discourse Analysis, An Overview, (Journal University of Granada, 2011) Vivian, John, Teori Komunikasi Massa. Jakarta: Kencana, 2008) 